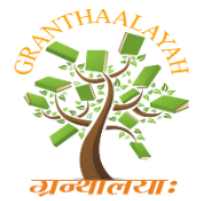

\author{
INTERNATIONAL JOURNAL OF RESEARCH - \\ GRANTHAALAYAH \\ A knowledge Repository
}

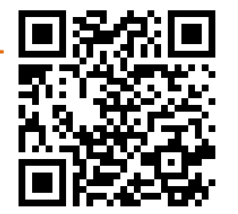

Science

\title{
OPTIMIZING NITROGENOUS FERTILIZER WITH AND WITHOUT COW DUNG ON THE GROWTH AND YIELD OF MAIZE (Zea mays L) IN DIGIL-MUBI, ADAMAWA STATE, NIGERIA
}

\author{
Mohammed D. Toungos *1 \\ ${ }^{* 1}$ Ph.D., Crop Science Department, Adamawa State University Mubi, Adamawa State of Nigeria
} Abstract

The research, optimizing nitrogenous fertilizer with and without cow dung on the growth and yield of maize (Zea mays L.) in Digil-Mubi, Adamawa state, Nigeria, was conducted in Farm and skills acquisition center Digil -Mubi, to determine the effects of nitrogenous fertilizer with and without cow dung on the growth and yield of maize (Zea mays L.) in the area. Seeds of maize was obtained from the open market in Mubi. Complete randomized design (CRD) was used and replicated three times. The trials were conducted during the 2018 cropping season at Digil - Mubi, Mubi Local Government, Adamawa state, Nigeria. Located in the Northern Guinea Savannah of Nigeria. Digil - Mubi is situated between latitude $10^{\circ} 10^{\prime \prime}$ and $10^{\circ} 30^{\prime \prime}$ North of the Equator and between longitude $13^{\circ} 10$ and $13^{0} 30^{\prime \prime} \mathrm{E}$ of the Greenwich meridian and at an altitude of $696 \mathrm{~m}$ above mean sea level (MSL). The results obtained, showed that, there were significant differences at $\mathrm{P} \leq 0.05$ in terms of yield between treatment two $(30 \mathrm{Kg} \mathrm{N}+0$ tone cow dung and $60 \mathrm{Kg} \mathrm{N}+5$ ton cow dung. But there were no significant difference at $\mathrm{P} \leq 0.05$ in terms of yield between $90 \mathrm{Kg} \mathrm{N}+5$ tones cow dung and $120 \mathrm{Kg} \mathrm{N}+5$ tones cow dung. However, luxuriant growth was observed in $120 \mathrm{Kg} \mathrm{N}+5$ tones cow dung than the $90 \mathrm{Kg} \mathrm{N}+5$ tones cow dung. Similarly, there were no significant difference in yield in the control plot ( $0 \mathrm{Kg} \mathrm{N}+0$ tone cow dung) and $30 \mathrm{Kg} \mathrm{N}+0$ tone cow dung. But the growth performance varies based on the treatment's combinations. The results obtained from this study showed that, combined application of nitrogen and cow dung in Digil Locality resulted in higher growth, yield and changes in some soil chemical properties than sole application of each nutrient source in the study area. The results also reveals that, the application of $90 \mathrm{Kg} \mathrm{N}+5$ tones of cow dung gave the highest yield of $2,928 \mathrm{Kg} / \mathrm{ha}^{-1}$ while $120 \mathrm{Kg} \mathrm{N}+5$ tones of cow dung gave the highest vegetative yield. The lowest grain of $1,796 \mathrm{Kg}^{-1}$ was obtained at $30 \mathrm{Kg} \mathrm{N}+0$ tone of cow dung. The application of $90 \mathrm{Kg} \mathrm{N}+5$ tones of cow dung is therefore recommended in Digil - Mubi and it surroundings for maximum yield and maintenance of soil fertility level in the area.

Keywords: Growth; Performance; Cow Dung; Luxuriant.

Cite This Article: Mohammed D. Toungos. (2019). "OPTIMIZING NITROGENOUS FERTILIZER WITH AND WITHOUT COW DUNG ON THE GROWTH AND YIELD OF MAIZE (Zea mays L) IN DIGIL-MUBI, ADAMAWA STATE, NIGERIA." International Journal of Research - Granthaalayah, 7(3), 264-273. 10.29121/granthaalayah.v7.i3.2019.968. 


\section{Introduction}

Maize ( Zea mays L.) is a member of the grass family (Poacea). It originated from South and Central America and later introduced to West Africa by the Portuguese in the $10^{\text {th }}$ Century (Olaniyi and Adewale, 2012). Maize is the staple food in Sub - Saharan Africa for an estimated 50\% of the population ( FAO 2006).

Maize crop requires adequate soil fertility for high productivity in which it requires relatively higher Nitrogen (N), Phosphorus (P) and Potassium (K) than other elements as opined by Ibrahim and Isa (2012). Idachaba, (2006), also reported that, maize output of countries correlate strongly and positively with fertilizer consumption. Moreover, maize respond favorably to fertilizer especially in the Savannah, where soils are generally low in native fertility ( Hussain et al, 2004). However, among the three most essential nutrients for proper growth and performance of maize, nitrogen and phosphorus are the most limiting in the Savannah soils, this is not unconnected with the vagaries of weather in the area.

Maize which is popularly known as "Corn" is one of the most versatile emerging cereal cash crops having wider adaptability under variety of climatic conditions. It is called the queen of cereals globally. The crop can be grown throughout the year in Northern Nigeria and more especially in Mubi, the study area which is the commercial nerve center of Adamawa State, Nigeria. Maize is also one of the three most important cereals grown in Nigeria along with sorghum and millet (USAID, 2010). Being a priority crop under the flagship agricultural programs of the Nigerian government since 2012. Maize is also the most important cereal crop in Sub-Saharan Africa, with rice and wheat; maize, rice and wheat, are one of the three most important cereal crops in the World (FAO, 2006).

Maize which is an important staple food crop is also the major crop cultivated in Mubi and its environments. However, the soil of the area are of low inherent fertility and require soil fertility management for proper growth and yield of the crop.

Despite the importance and increase in number of farmers to maize production, yield per hectare is still relatively low in the study area due to the low fertility levels. This is in addition to the low organic matter content, low CEC, low water holding capacity. In order to increase yield inorganic and organic fertilizers needs to be applied in order to increase yield production in Digil-Mubi. The use organic fertilizers may go a long way in providing solutions to low crop yield as a result of lack of inorganic fertilizers (Tunku, 2012). Organic manure is found to check erosion, leaching of nutrients, evaporation losses and remains longer in soil and releases nutrients slowly making it available to plants (FAO, 2004; Das, 2005). Shalt et al (2009) reported that, imbalance use of fertilizer without application of farmyard manure (FYM) and not knowing the requirements of crops and the fertility status of the soil causes deterioration of soil structure and continues use of chemical fertilizer without FYM causes the depletion of soil fertility. For soil to be sustained for crop productivity, it is necessary to explore alternative soil fertility replacement strategies, which are effective and affordable to farmers, especially the small holder ones. Despite the increase in total production of maize, yield per hectare is still relatively low, due to low fertility status, scarcity and limited use of inorganic fertilizers. Smallholder farmers have attempted the use of fertilizers such as NPK, which are generally very scarce and when available is very expensive and beyond the reach of resource poor farmers, but its application is necessary for proper performance of 
maize. Hence, there is the need to explore strategies for improving and management of soil fertility for maximum output per unit area by investigating the effects of Nitrogen and Cow dung fertilizers and their combination on maize growth and yield with some selected soil chemical properties that will enhance production against an increasing population. This research, therefore, evaluated the effects of nitrogen and Cow dung fertilizers and their combination on the growth and some selected soil chemical properties to enhance the best management practices on improving productivity to the resource poor farmers of the area so as to meet the increasing demand of food due to population explosion.

Nutrients requirements of maize: The amount of nutrient s required by maize plant depends mainly on two factors:

i. the projected maize yield that appears attainable in the locality, and;

ii. the fertility level of the soil as determined by soil test.

Maize is said to have a high demand for Nitrogen and it is often the limiting nutrient in maize production. The improved hybrids can only reach their fullest expression when they are grown at high plant densities (Onwuemen and Singha, 1991). Maize requirements varies with the varieties of maize as well as the nutrient content (Organic and inorganic nutrients) for hybrids and open pollinated (composites) varieties of maize exhibit their full yield potential only when supplied with adequate quantities of nutrients at proper time. However, hybrid varieties of maize require more nutrients compared to open-pollinated varieties of maize. The general recommendation one can apply for hybrid per hectare is thus: $120 \mathrm{KgN}, 60 \mathrm{Kg} \mathrm{P}_{2} \mathrm{O}_{5}$ and $40 \mathrm{Kg} \mathrm{K}_{2} \mathrm{O}$; while the open-pollinated maize could apply: $80 \mathrm{KgN}, 30 \mathrm{KgP}_{2} \mathrm{O}_{5}$ and $20 \mathrm{Kg} \mathrm{K} 2 \mathrm{O}$, Chidda et al 2010). However, Owueme and Sinha (1991) gave the general recommendation (unspecified) for maize nutrient requirement, if the soils are deficient in $\mathrm{P}$ and in $\mathrm{K}$ a dose of: $100-150 \mathrm{Kg} \mathrm{N}, 40-50 \mathrm{Kg} \mathrm{P}_{2} \mathrm{O}_{5}$ and 80-100 Kg $\mathrm{K}_{2} \mathrm{O}$ per hectare will be applied to obtain grain yields of 6-7tonnes of maize per hectare. Moreover, Chidda et al., (2010) also gave an unspecified general recommendation on a crop of maize yielding about 14 tones of dry matter (both grain and Stover) by the application of $161 \mathrm{KgN}, 34 \mathrm{KgP}$ and $110 \mathrm{Kg} \mathrm{k}$ per hectare.

Since maize requires more nitrogen as a source of nutrients than $\mathrm{P}$ and $\mathrm{K}$, it is advisable to apply the total quantity of $\mathrm{P}$ and $\mathrm{K}$ and one-third of $\mathrm{N}$ at planting and split up remaining two-thirds of $\mathrm{N}$ in two equal doses, one at the knee height stage (2-3 weeks or 30-50days after planting) and the rest at tasseling stage.

Organic manures also play an important role in maize cultivation. The application of organic matter to the soil ensures good tilth and improves water holding capacity (Chidda et al., 2010). It is therefore, advisable to apply organic manures before ploughing to improve soil structure and supply nutrients (Brink and Belay 2006). Awotundun et al., (2000) recommended the organic nutrient requirements per hectare of an open-pollinated maize as 3 tones of either: cow dung manure, sheep manure, poultry manure, rabbit manure or farm yard manure (FYM). Yayock and Awoniyi (1974) reported that, 7.6 tones/ha of FYM would supply $82-100 \mathrm{KgN}, 25-30 \mathrm{Kg}_{2} \mathrm{O}_{5}$ and $70-85 \mathrm{Kg}$ of $\mathrm{K}_{2} \mathrm{O} / \mathrm{ha}$.

Organic manures are of great importance in different numbers of farming situations. It is very valuable in raising vegetables and also supplies most important plant nutrients to arable crops, 
(Awotundun, 1995). Wild (1988) observed that, animal manure is a source of all plant nutrients including nitrogen, calcium, magnesium, potassium, and sodium. But however, it is difficult to recommend particular animal manure because of the varying quality based on the materials they fed on (Awotundun et al., 2000). Animal manures are affected by three factors: age of the animal; types of animals used and feed on which animals were fed before producing the dungs or droppings. Young animals make use of all available nutrients in the feed for growth and development, while older ones produce manure with more quality than younger animals. Ruminants such as cattle, sheep or goats produce better quality manure than monogastric animals suck as pigs. The quality of feed on which animals fed on during the production of the applied manure affect the quality of the particular manure (Fernandes and Sanchez, 1990). However, despite the failing or higher quality of animals manures, they still compared favorably with compound fertilizer in terms of grain yield. They can also be used as an alternative to the expensive chemical fertilizers (Awotundun et al., 2000).

Fertility status of soils in Mubi: Based on the literature reviews on the fertility levels of Mubi conducted by Ekwue and Tashiwa (1992); Tekwa et al (2011), the soils of the area are predominantly loamy-textured with high percentage sand (49-76\%). At the study area, Digil, the organic matter content was relatively high and decreased with soil depths. Total $\mathrm{N}$ was low while available $\mathrm{P}$ and $\mathrm{K}$ are moderate to adequate. Exchangeable $\mathrm{Ca}$ and $\mathrm{Mg}$ increases with depths. This trends follows along Muvur and Lamurde but increases at Vimtim but fluctuated in areas such as Gella and Madanya. But in the areas of Gella and Muvur, the soil reaction was slightly acidic. While total exchangeable bases (TEB) and basic cations $\left(\mathrm{Ca}^{2+}, \mathrm{Mg}^{2+}, \mathrm{K}^{+}\right)$appears to be low. The Cation Exchange Capacity (CEC) of the soils tends to be low due to the variation in $\mathrm{Ca}, \mathrm{Mg}$ and OM Content varies at various soil depths. Generally, soils texture varied from silky loam sandy loam at the study area. The variations might be attributed to the periodic selective soil deposition and leveraged occasioned by poor drainage conditions as observed by Ekwueme and Tashiwa, 1992; and Tekwa and Usman, 2006).

Bulk density: the bulk density of the soil in the reperch area generally ranges from $1.18-1.51 \mathrm{~g}^{\mathrm{cm}-}$ 3 with mean value of $1.33 \mathrm{gcm}^{-3}$. This might not be unrelated to over grazing and soil compaction in the area as it is a Fulani dominated with large herds of cattle. This might also be the reason why low yield is realized in the area due to compaction of the soil and poor penetration of roots to sustain the crops for maximum output.

Soil reaction: the soil in the area is moderately acidic (5.96) to strongly acidic (5.09) soil reaction. Generally the $\mathrm{P}^{\mathrm{H}}$ range is between 5.09-5.96 with a mean of 5.36, indicating that the soil was slightly acidic (Tekwa et al., 2011). The soil OM generally varies in depletion with soil depths as observed by Brady and Weil, 2002. The OM content was $0.67 \%$. However, organic matter content generally vary with rainfall and clay content (Kadeba, 1978 and Jones, 1973). The total nitrogen in Digil ranges between $0.15-0.16 \%$. at between 0 and $50 \mathrm{~cm}$ soil depths. Jones and Wild (1975) observed that, clay content and rainfall are responsible for the variation in total nitrogen generally. Noting the low level of nitrogen in the soil, it is imperative to use appropriate $\mathrm{N}$ fertilizer for the production of maize in Digil which needs high $\mathrm{N}$ requirements and cannot fix the atmospheric nitrogen to meet it growth requirements. 


\section{Materials and Methods}

The research, effects of nitrogenous fertilizer with and without cow dung on the growth and yield of maize (Zea mays L) in Digil-Mubi, Adamawa state, Nigeria, was conducted in Farm and skills acquisition center Digil -Mubi which lies between latitude $9^{0} 30^{\prime}$ and $11^{0}$ north of the equator and longitude $13^{\circ}$ and $13^{0} 45^{\prime}$ east of Green Meridian at an altitude of $696 \mathrm{~m}$ above sea level in the northern savannah ecological zone of Nigeria. (Adebayo, 2004)

The climate of the study area is characterized by alternating dry season from November to March and a wet season from April to October. The main annual rainfall ranges from $700 \mathrm{~mm}$ to $1,050 \mathrm{~mm}$. the seasonal maximum temperature of $37.0^{\circ} \mathrm{C}$ occurs in April and minimum of $12.7^{\circ} \mathrm{C}$ in January. Maximum relative humidity is $90 \%$ while minimum is $50 \%$ (Adebayo, 2004). The soil of the study area falls under the category of lithosols following the guidelines of FAO/UNESCO soil classification, characterized by rocky-basement within shallow depths from the soil surface and orchard type vegetation due to its limitation to inherent fertility with undifferentiated basement complex parent material represented by magnitude -gneisses, schist, quartzites, pegmatite, diorite and amphibolite's (Nwaka, et al., 1999 and Adebayo, 2004).

\section{Treatments and experimental design:}

The treatments consisted of five rates of nitrogen $(0,30,60,90$ and $120 \mathrm{Kg} / \mathrm{ha})$ and two levels of cow dung ( 0 and 5 tones/ha). The treatments were combined factorially which gave 10 treatments as can be seen in table 1 below was replicated three times and laid in a complete Randomized Design (CRD) as presented in table II. This was imposed and mixed thoroughly to a lower plasticity with $3 \mathrm{Kg}$ of soil weighted and filled in the perforated plastic pots of $49.1 \mathrm{~cm}$ diameter and $17 \mathrm{~cm}$ depth to three quarter, while one quarter was allowed for watering. The treatments designed $\left(30,60,90\right.$ and $\left.120 \mathrm{Kg} / \mathrm{ha}^{-1}\right)$ was applied as NPK 15:15:15 and urea as a source of $\mathrm{N}$, while SSP was applied as a source of $\mathrm{P}$ which made up the recommended $\mathrm{P}$ rate $\left(60 \mathrm{Kg} \mathrm{P} / \mathrm{ha}^{-1}\right)$ and NPK applied provided the recommended $\mathrm{K}$ rate $\left(40 \mathrm{Kg} \mathrm{K} / \mathrm{ha}^{-1}\right)$, whereas the cow dung obtained from the herds of the farmers' in the area was applied at a level of (5tons $\left./ \mathrm{ha}^{-1}\right)$. The amount of fertilizers and cow dung needed for each pot was calculated using furrow-slice method (Babaji, et al., 2006).

Table 1: Number of treatments

\begin{tabular}{ll}
\hline S/NO & Treatments \\
\hline 1. & $0 \mathrm{Kg} \mathrm{N}+0$ ton cow dung (control) \\
2. & $30 \mathrm{Kg} \mathrm{N}+0$ ton cow dung \\
3. & $60 \mathrm{Kg} \mathrm{N}+0$ ton cow dung \\
4. & $90 \mathrm{Kg} \mathrm{N}+0$ ton cow dung \\
5. & $120 \mathrm{Kg} \mathrm{N}+0$ ton cow dung \\
6. & $0 \mathrm{Kg} \mathrm{N}+5$ tones cow dung \\
7. & $30 \mathrm{Kg} \mathrm{N}+5$ tones cow dung \\
8. & $60 \mathrm{Kg} \mathrm{N}+5$ tones cow dung \\
9. & $90 \mathrm{Kg} \mathrm{N}+5$ tones cow dung \\
10. & $120 \mathrm{Kg} \mathrm{N}+5$ tones cow dung \\
\hline
\end{tabular}


Table 2: Pots arrangement of the ten treatments with three replications using Complete

\begin{tabular}{|c|c|c|c|c|c|c|c|c|c|c|}
\hline \multicolumn{11}{|c|}{ Randomized Design (CRD) } \\
\hline & 1 & 2 & 3 & 4 & 5 & 6 & 7 & 8 & 9 & 10 \\
\hline R1 & $\begin{array}{l}0 \mathrm{Kg} \mathrm{N}+0 \text { ton } \\
\text { cowdung (control) }\end{array}$ & $\begin{array}{l}30 \mathrm{Kg} \mathrm{N} \\
+0 \text { ton } \\
\text { cowdung }\end{array}$ & $\begin{array}{l}60 \mathrm{Kg} \mathrm{N} \\
+0 \text { ton } \\
\text { cowdung }\end{array}$ & $\begin{array}{l}90 \mathrm{Kg} \mathrm{N}+0 \text { ton } \\
\text { cowdung }\end{array}$ & $\begin{array}{l}120 \mathrm{Kg} \\
\mathrm{N}+0 \\
\text { ton } \\
\text { cowdung }\end{array}$ & $\begin{array}{l}0 \mathrm{Kg} \mathrm{N}+ \\
5 \text { ton } \\
\text { cowdung }\end{array}$ & $\begin{array}{l}30 \mathrm{Kg} \mathrm{N} \\
+5 \text { ton } \\
\text { cowdung }\end{array}$ & $\begin{array}{l}60 \mathrm{Kg} \mathrm{N} \\
+5 \text { ton } \\
\text { cowdung }\end{array}$ & $\begin{array}{l}90 \mathrm{Kg} \mathrm{N} \\
+5 \text { ton } \\
\text { cowdung }\end{array}$ & $\begin{array}{l}120 \mathrm{Kg} \mathrm{N}+5 \text { ton } \\
\text { cowdung }\end{array}$ \\
\hline R2 & $\begin{array}{l}120 \mathrm{Kg} \mathrm{N}+5 \text { ton } \\
\text { cowdung }\end{array}$ & $\begin{array}{l}90 \mathrm{Kg} \mathrm{N} \\
+5 \text { ton } \\
\text { cowdung }\end{array}$ & $\begin{array}{l}60 \mathrm{Kg} \mathrm{N} \\
+5 \text { ton } \\
\text { cowdung }\end{array}$ & $\begin{array}{l}30 \mathrm{Kg} \mathrm{N}+5 \text { ton } \\
\text { cowdung }\end{array}$ & $\begin{array}{l}120 \mathrm{Kg} \\
\mathrm{N}+0 \\
\text { ton } \\
\text { cowdung }\end{array}$ & $\begin{array}{l}90 \mathrm{Kg} \mathrm{N} \\
+0 \text { ton } \\
\text { cowdung }\end{array}$ & $\begin{array}{l}60 \mathrm{Kg} \mathrm{N} \\
+0 \text { ton } \\
\text { cowdung }\end{array}$ & $\begin{array}{l}30 \mathrm{Kg} \mathrm{N} \\
+0 \text { ton } \\
\text { cowdung }\end{array}$ & $\begin{array}{l}0 \mathrm{Kg} \mathrm{N}+ \\
5 \text { ton } \\
\text { cowdung }\end{array}$ & $\begin{array}{l}0 \mathrm{Kg} \mathrm{N}+0 \text { ton } \\
\text { cowdung(control) }\end{array}$ \\
\hline R3 & $\begin{array}{l}120 \mathrm{Kg} \mathrm{N}+0 \text { ton } \\
\text { cowdung }\end{array}$ & $\begin{array}{l}90 \mathrm{Kg} \mathrm{N} \\
+0 \text { ton } \\
\text { cowdung }\end{array}$ & $\begin{array}{l}120 \mathrm{Kg} \\
\mathrm{N}+5 \\
\text { ton } \\
\text { cowdung }\end{array}$ & $\begin{array}{l}0 \mathrm{Kg} \mathrm{N}+0 \text { ton } \\
\text { cowdung(control) }\end{array}$ & $\begin{array}{l}0 \mathrm{Kg} \mathrm{N}+ \\
5 \text { ton } \\
\text { cowdung }\end{array}$ & $\begin{array}{l}60 \mathrm{Kg} \mathrm{N} \\
+0 \text { ton } \\
\text { cowdung }\end{array}$ & $\begin{array}{l}90 \mathrm{Kg} \mathrm{N} \\
+5 \text { ton } \\
\text { cowdung }\end{array}$ & $\begin{array}{l}30 \mathrm{Kg} \mathrm{N} \\
+5 \text { ton } \\
\text { cowdung }\end{array}$ & $\begin{array}{l}60 \mathrm{Kg} \mathrm{N} \\
+5 \text { ton } \\
\text { cowdung }\end{array}$ & $\begin{array}{l}30 \mathrm{Kg} \mathrm{N}+0 \text { ton } \\
\text { cowdung }\end{array}$ \\
\hline
\end{tabular}

Soil sampling and preparation: the soil for the experiment was collected from uncultivated land at Digil Village. Bulk sample was taken at a depth of $0-30 \mathrm{~cm}$ using augur and small quantity of the sample was used for analysis.

Preparation of soil sample for analysis: The soil sample was air-dried and crushed using a wooden mortar and pestle, then sieved through a $2 \mathrm{~mm}$ mesh. The sieved sample was stored in polythene bags and analyzed laboratory for physio-chemical properties, before and after the experiment, namely:

i. the particle size distribution was determined using Bouyocous Hydrometer Method (Trout et al., 19870;

ii. $\quad$ Soil bulk density was determined using clod method (Klute, 1986);

iii. Soil reaction $\mathrm{P}^{\mathrm{H}}$ was determined using the $\mathrm{P}^{\mathrm{H}}$ meter method (soil/water ratio of 1:2.5), while electrical conductivity (EC) was determined in soil/water extract using an EC meter (Page et al., 1982);

iv. Organic carbon was determined by dichromate digestion (Walkey and Black, 1934), from where the organic matter was calculated;

v. Total nitrogen $(\mathrm{N})$ was determined by Kjedahl's method (Bremner and Mulvaney, 1982);

vi. Available Phosphorus (P) was extracted by Bray No. 1 method (Bray and Kurtz, 1945);

vii. Available Potassium $(\mathrm{K})$ was determined by flame photometer using routine analytical methods, IITA (1979);

viii. Water holding capacity (WHC) was determined by gravimetric method (Trout et al., 1987);

ix. Exchangeable Acidity (EA) was extracted with 1 Normal KCL and the percentage base saturation (PBS) was calculated as the sum of the bases \{total exchangeable bases, (TEB) divided by CEC and expressed as percent using the routine analytical methods by IITA (1979).

\section{Crop management}

Sowing: Five seed of maize per pot was sown at a depth of $2-3 \mathrm{~cm}$ and then thinned to three plants per pot, a week after sowing (WAS).

Watering: watering was done once daily in the evening and soil water content kept as close to field capacity (FC) as possible by weighing one pot to estimate water loss and water was added to the pots to maintain the water content of the soil at FC. Moisture meter was used in keeping the 
soil moist, that avoided leaching of nutrients. The water used was a good quality suited for irrigation.

Weeding: Emerged weeds were hand pulled immediately, that avoided nutrient competition.

Harvesting: The shoots and roots of each of the plant in the pots were harvested after weeks (8WAS). The shoots was harvested by cutting the stem about $1 \mathrm{~cm}$ above the ground, while the roots was harvested by soaking the pots in a bucket filled with water and washed until all soil particles was removed. The supernatant suspension with the roots was transferred onto a $0.5 \mathrm{~mm}$ sieve where all broken roots were trapped. The shoot and the root component harvested were kept in a paper envelop and oven dried at a temperature of $60^{\circ} \mathrm{C}$ for 48 hours and their weights were recorded as a total dry matter.

Data collection: Growth parameters measured were: Plant height, Number of leaves and Leave area. The data was recorded weekly, for a maximum of eight weeks after sowing (8WAS) and all the parameters were recorded for each of the plants (90 plants) and their average was taken appropriately.

Plant height: plant height was taken using a measuring tape graduated in $\mathrm{cm}$. Measurements started from the ground level to the last flag leaf and all the results recorded.

Number of leaves: number of leaves per plant of each pot were counted and recorded.

Leaf area: The leaf area was estimated by measuring the leaf length and maximum width and multiplying by a factor 0.70 i.e. maize leaf calibration factor and the results were recorded.

Statistical analysis: All the data collected were subjected to analysis of variance (ANOVA) using statistical Application for Sciences (SAS,1991).

\section{Results and discussion}

The results indicated that, Spot Soil properties vary spatially from the field which is also in agreement with the work of Cambardella, C. A, and Karlen, D.L. (1999) on Spatial analysis of soil fertility parameters. That, Such spatial variability and differences in soil fertility within and between farms have considerable effects on resource use efficiency and crop performance. Table 3 shows the physical and Chemical Characteristics of Soils of the study area, Digil -Mubi, Adamawa State.

There were significant differences at $\mathrm{P} \leq 0.05$ in terms of yield between treatment two $(30 \mathrm{Kg} \mathrm{N}+$ 0 tone cow dung and $60 \mathrm{Kg} \mathrm{N}+5$ ton cow dung. But there were no significant difference at $\mathrm{P} \leq$ 0.05 in terms of yield between $90 \mathrm{Kg} \mathrm{N}+5$ tones cow dung and $120 \mathrm{Kg} \mathrm{N}+5$ tones cow dung. However, luxuriant growth was observed in $120 \mathrm{Kg} \mathrm{N}+5$ tones cow dung than the $90 \mathrm{Kg} \mathrm{N}+5$ tones cow dung. Similarly, there were no significant difference in yield in the control plot $(0 \mathrm{Kg}$ $\mathrm{N}+0$ tone cow dung) and $30 \mathrm{Kg} \mathrm{N}+0$ tone cow dung. But the growth performance varies based on the treatments combinations. This is in agreement with the work of Verhults, et al., (2014) on nitrogen use efficiency and optimization in some maize varieties.

The results of the soil physical and chemical characteristics at the experimental site before conducting the experiment are presented in Table 3. There were little to no differences in terms of $\mathrm{EC}\left(\mathrm{dSm}^{-1}\right), \mathrm{P}^{\mathrm{H}}\left(1: 2.5\right.$ Soil $\left.\mathrm{H}_{2} 0\right)$, O.M $(\%)$ and $\mathrm{N}(\%)$ however there were some spot differences in terms of $\mathrm{P}\left(\mathrm{Mg} \mathrm{Kg}^{-1}\right)$ and Particle Size Sand Silt Clay as can be seen on the table. The findings are in agreement with work of Hamza and Anderson (2003), that Cation exchange Capacity and exchangeable calcium increased more on clay soils than on sandy soils. 
The growth parameters, such as plant height, leaf area and number of leaves vary based on treatments. The highest plant height and number of leaves were observed at $120 \mathrm{Kg} \mathrm{N}+5$ tones cow dung, which longest lea area was recorded at $90 \mathrm{Kg} \mathrm{N}+5$ tones cow dung. The trends followed from lower rates to higher rates except at the control $0 \mathrm{Kg} \mathrm{N}+0$ ton cow dung and $0 \mathrm{Kg} \mathrm{N}+0$ ton cow dung.

Table 3: physical and Chemical Characteristics of Soils of Digil -Mubi, Adamawa State

\begin{tabular}{|c|c|c|c|c|c|c|c|c|c|c|c|c|}
\hline & $\begin{array}{l}\text { Depth } \\
\text { (Cm) }\end{array}$ & $\begin{array}{l}\text { EC } \\
(\text { dSm- } \\
\text { 1) }\end{array}$ & $\begin{array}{l}\mathrm{P}^{\mathrm{H}} \\
(1: 2.5 \\
\text { Soil } \\
\left.\mathrm{H}_{2} \mathbf{0}\right) \\
\end{array}$ & $\begin{array}{l}\text { O.M } \\
(\%)\end{array}$ & $\begin{array}{l}\mathrm{N} \\
(\%)\end{array}$ & $\begin{array}{l}\mathbf{P} \\
(\mathbf{M g} \\
\left.\mathbf{K g}^{-1}\right)\end{array}$ & $\begin{array}{l}\text { K Ca Mg } \\
\left(\mathbf{C m o l}(+) \mathrm{Kg}^{-1}\right.\end{array}$ & TED & B.D & $\begin{array}{l}\text { Particle Size } \\
\text { Sand Silt Clay }\end{array}$ & EA CEC BS & Textural Class \\
\hline Digil- & $0-20$ & 0.03 & 5.57 & 0.67 & 0.15 & 17.21 & $3.29 \quad 9.02 \quad 2.21$ & 15.45 & 1.51 & $\begin{array}{llll}54.95 & 17.50 & 32.55\end{array}$ & $\begin{array}{lll}1.0 & 3.51 & 72.55\end{array}$ & Sandy Clay \\
\hline Mubi. & $20-30$ & 0.04 & 5.53 & 0.67 & 0.16 & 14.12 & $\begin{array}{lll}2.41 & 9.21 & 2.51\end{array}$ & 15.23 & 1.44 & 56.2013 .2031 .60 & 1.03 .3771 .59 & $\begin{array}{l}\text { Loam SCL } \\
\text { Sandy Clay } \\
\text { Loam SCL }\end{array}$ \\
\hline
\end{tabular}

Source: Tekwa et al,. (2011)

\section{Conclusion}

The results obtained from this study showed that, combined application of nitrogen and cow dung in Digil Locality results in high growth, yield and changes in some soil chemical properties than sole application of each nutrient source in the study area. The result also reveals that, the application of $90 \mathrm{Kg} \mathrm{N}+5$ tones of cow dung gave the highest yield of $2,928 \mathrm{Kg} / \mathrm{ha}^{-1}$ while $120 \mathrm{Kg}$ $\mathrm{N}+5$ tones of cow dung gave the highest vegetative yield. The lowest grain of $1,796 \mathrm{Kg}^{-1} \mathrm{was}$ obtained at $30 \mathrm{Kg} \mathrm{N}+0$ tone of cow dung. The application of $90 \mathrm{Kg} \mathrm{N}+5$ tones of cow dung is therefore recommended in Digil - Mubi and it surroundings for maximum yield and maintenance of soil fertility level in the area.

\section{References:}

[1] Adebayo, A.A (2004). Mubi Region: A Geography Synthesis ( $1^{\text {st }}$ Eds). Paraclete Publishers, Yola - Nigeria. Pp. $32-38$.

[2] Apraku, B.B., Fakorede, M.AB., Onedrago, M., Carsky, R.J., and Menkir, C. (2003). Maize Revolution in West and Central Africa. West and Central African Collaborative Maize Research Network; Ibadan. Pp. 225

[3] Awotundun, J.S. (1995). Field Evaluation Nitrogen and its Concentration in Lettuce and Amaranthus Leaves. NewsLetter, No. 1 - 2

[4] Awotundun, J.S., Okunlade, O.A. and Oyinlola, R. (2000). Comparative effect of Organic and Inorganic Fertilizers on the yield of Open-Pollinated Maize. In Babablola, O., Ogunkule,

[5] A.O., Olayinka, A., Fagbemi, A.A., Agboola, A.A., and Ewenzor (eds). Proceedings of the $26^{\text {th }}$ Annual Conference of the Soil Science Society of Nigeria held at Ibadan, Nigeria, October 30 November 3 (2000) by Soil Science Society of Nigeria. Pp. 136-336.

[6] Babaji, B.A., Ali, R.I., Yahya, R.A., Mahali, M.A. and Shavifai, A.I. (2006). Nitrogen and Phosphoru Nutrition odf Sessame (Sesanum indicum L.) at Savanna Nigeria. Proceedings Of the $31^{\text {st }}$ Annual Conference of the Soil Science Society of Nigeria 329-336.

[7] Brady, N.C. and Weil, R.R (2002). The Nature and Properties of Soil. (13 ${ }^{\text {th }}$ Edition) Pearson Edu. Pub., New Delhi: India.

[8] Bray, R.H. and Kurts, L.T. (1945). Determination of Total Organic and Available Phosphorus in Soils. Soil Science 59, 39-45. 
[9] Bremmer, J.M. and Mulvancy, C.S. (1982). Total Nitrogen in Methods of Soil Analysis Part 2. Chemical and Microbiological Properties. In Page, A. L., Miller, R.H. and Keeney, D.R (Eds) Agronomy Monograph No. 9. ( $2^{\text {nd }}$ Edition) American Society of Agronomy, Inc., Soil Science Society of America, Inc. Publisher, Madison Wisconsin 53711, USA, Pp.595-622.

[10] Brink, M. and Belay, G. (2006). Plant Resources of Tropical Africa I: Cereals and Pulses. Published by PROTA Foundation/Backhuys/CTA, Wageningen, Netherlands ISBN 90-5782-1702. Pp. 228-237.

[11] Cambardella, C. A., and Karlen DL. (1999). Spatial analysis of soil fertility parameters. Precis Agric. 1:5-14.

[12] Chhhdda, S., Prem, S. and Rajbir, S. (2010). Modern Techniques of Raising Field Crops. (2 $2^{\text {nd }}$ Ed.). Published by Oxford and IBH Company, Ltd., New Delhi (India). 110049 Pp. 84, 99-100.

[13] Das, P.C. (2005). Manures and Fertilizers. $2^{\text {nd }}$ Ed. Kalyan Publishers. New Delhi. Pp. 75-76.

[14] Ekwue,.E.I. and Tashiwa, Y.I. (1992). Survey of Gully Erosion Features in Mubi LGA of Adamawa State. Annals of Borno 8/9: 181-191.

[15] Food and Agricultural Organization (FAO). (2004). Fertilizer use by Crops in Pakistan. Pp. 4-24. In Pakistan Journal of Life and Social Sciences (2009). 7(2): 108-111.

[16] Food and Agricultural Organization ( F.A.O) STAT., (2006). Food and Agricultural Statistics, www.fao.org. retrieved march, 2019.

[17] Fernandes, E.C.M., and Sanchesz, P.A. (1990). The Role of Organic input and Soil Organic Matter for Nutrient cycling in Tropical Soil. Inorganic matter management and tillage in humid and sub-humid African, Bangkok, Thailand. IBSRAM.

[18] Hamza, M.A,. and Anderson, W.K (2003). Responses of Soil properties and grain yield to deep ripping and gypsum application in a compacted loamy soil contrasted with sandy clay loam soil in Western Autralia. Australian Journal of Agricultural Research, 54(3), 272-282. https://doi.org/ 10.1071/AR01202.

[19] Hussain, M.A., Mohammed, S.G. and Jibrin, J.M. (2004). Effects of different Levels of Nitrogen and Phosphorus on the Performance of Maize (Zea Mays L) under varying Irrigation Regimes in the Sudan Savanna Zone. Journal of Arid Agriculture. 14: 85-91.

[20] Ibrahim, H. and Isa, H.M., (2012). Growth attributes of Maize (Zea Mays L.) Varieties as Influenced by different rates of Nitrogen Fertilizer. In Jibrin J.M., Hussaini, M.A.,

[21] Auwalu, B.M., Essiet, E.U., Muhammad, I.R., Mohammed, S.G., Daneji, M.I., Garba, Y. and Pantami, S.A.(eds). Agricultural Transformation in a Deregulated Economy: Prospects and Challenges. Proceeding of the $46^{\text {th }}$ Annual Conference of the Agricultural Society of Nigeria, November $5^{\text {th }}-9^{\text {th }}, 2012$. Pp. 896.

[22] International Institute of Tropical Agriculture (I.I.T.A) 1979. Selected Methods of Soil and And Plant Analysis. Manual Series No:1. I.I.T.A Ibadan, Nigeria.

[23] Idachaba, F.S. (2006). An Overview of Nigeria's Fertilizer Sector. Paper Presented at the International Fertilizer Policy Workshop. Unpublished M.Sc. Thesis, A.B.U Zaria. Pp in Agricultural Society of Nigeria Proceedings, $46^{\text {th }}$ Annual Conference Held at Kano, Nigeria, November $5^{\text {th }}-9^{\text {th }}, 2012$ Pp. 891.

[24] Jones, M.J. and Wild, A. (1973). The Organic Matter Content of Savanna Soils of West Africa. Journal of Soil Science 24. 42-53.

[25] Jones, M.J. and Wild, A. (1975). Soils of West African Savanna. Technical Communication No: 55. Common Wealth Bureau of Soil Harpenden, Farnhan Royal, Bucks.

[26] Kadeba, O. (1978). Organic Matter Status of Some Soils of Northern Nigeria. Soil Science 125, 122-127.

[27] Klute, A. (1986). Methods of Soil Analysis. Part 1, Agronomy No. 9, American Society of Agronomy, Madison, Wisconsin, USA.

[28] Nwaka, G.I.C., Kwari, J.D. and Shukla, U.C (1993). A StUDY OF Soils Derived from Basalt in North-Eastern Nigeria II. Physico-Chemical Characteristics and Fertility Status. Journal Of Arid Agriculture, 9: 89-98.Maiduguri, Nigeria. 
[29] Olaniyi, O.A. and Adewale, J.G. (2012). Information on Maize Production Among Rural Youth: A Solution for Sustainable Food Security in Nigeria. University of Technology

[30] Onwueme, .I.C. and Sinha, T.D. (1991). Field Crop Production in Tropical Africa. By Technical Centre for Agriculture and Rural Cooperation (CTA) Publishers Netherlands ISBN No. 92,9081 0866. Pp. 159-171.

[31] Page, A.L,. Miller, R.H and Keeney, D.R, (1982). Methods of Soil Analysis.Part 2. Agronomy No. 9, American Society of Agronomy, Madison, Wisconsin, USA.

[32] SAS (1991). Statistical Application for the Sciences Institute, Inc., NC, USA.

[33] Singh, L. and Balasubraminian, V. (1983). Crop Response to Potassium on the Savanna Soils of Nigeria. Experimental Agriculture 15, 257-265.

[34] Tekwa, I.J. and Usman, B.H. (2006). Estimation of Soil Loss by Gully Erosion in Mubi, Adamawa State, Nigeria. Journal of Environment. 1. 1:35-43. Published by School of Environmental Sciences, Federal University of Technology, P.M.B 2076, Yola, Nigeria.

[35] Tekwa,I.J,. Shehu, H.E,. and Maunde, S.M. (2011). Soil Nutrient Status and Productivity Potentials of Lithosols in Mubi Area, North-Eastern Nigeria. Agricultural and Biological Journal of North America, 2 (6): 887-896.

[36] Trout, T.J., Gareia-Castilas, I.G., and Hyart, W.E. (1987). Soil Water Engineering. Field and Laboratory Manual. M/S Eurasia, New Delhi. India.

[37] Tunku, P. (2012). Comparative Effects Inorganic and Organic Fertilizers on the Performance of Okra (Albelmoschus esculentus (L). MOENCHH). In Jibrin J.M., Hussaini, M.A., Auwalu, B.M., Essiet, E.U., Muhammad, I.R., Mohammed, S.G., Daneji, M.I., Garba, Y. and Pantami, S.A.(eds). Agricultural Transformation in a Deregulated Economy: Prospects and Challenges. Proceeding of the $46^{\text {th }}$ Annual Conference of the Agricultural Society of Nigeria, November $5^{\text {th }}$ $9^{\text {th }}$, 2012. Pp. 890-891.

[38] United States Agency for International Development (USAID), 2010. Packages of practices for maize production. Prepared by USAID/Maximizing Agricultural Revenues and Key Enterprises in Targeted Sites (MARKETS).

[39] Verhulst, N., Francois, I., Grahmann, K., Govaret, B., \& Cox, R. (2014). Nitrogen use efficiency And optimization of nitrogen fertilization in conservation Agriculture. CIMMYT. Pp.4.

[40] Walkey, A. and Black, C. (1934). An Examination of Destjaeff Method for Determining Soil Organic Matter with Chromatic Acid Titration Method. Soil Science Society of American Journal 37: 29-38.

[41] Watson, K.A. and Goldsworthy, P.R (1964). Soil Fertility Investigation in the Middle Belt of Nigeria. The Empire Journal Expert Agriculture. 32: 290-302.

[42] Wild, A. (1988). Soil Condition and Plant Growth, Longman, London Pp. 1-30.

[43] Yayock, T.Y. and Awoniyi, J.O. (1974). Organic Manure, Industrial Waste and Chemical Fertilization of Maize and Sorghum. Samaru Agriculture Newsletter 16: (1) 37-39.

*Corresponding author.

E-mail address: dahiru.toungos@ gmail.com/toungosm@ adsu.edu.ng 